\title{
P53 overexpression in epidermoid carcinoma of the head and neck
}

\author{
Department of Head and Neck Surgery, A.C. Camargo Hospital, Fundação Antonio Prudente - São Paulo, Brazil
}

The theory of field cancerization in tumors of the head and neck reflects the complex oncogenesis that occurs in this region. The mechanisms that control cell proliferation at the molecular level in epidermoid carcinomas (ECs) of the upper aerodigestive tract are still unclear. Mutations in p53 are the genetic alterations most often detected in ECs of the head and neck and seem to contribute actively to the carcinogenic process triggered by p53 as a tumor-suppressor gene and to its association with tobacco. The objective of the present study was to investigate the expression of $\mathrm{p} 53$ protein in epidermoid head and neck carcinomas by immunohistochemistry and its immunohistochemical correlation with other prognostic factors. The study was conducted on 63 consecutive ECs cases not submitted to previous treatment. Specimens of the tumor and of the normal adjacent mucosa were collected during surgery and submitted to immunohistochemical reaction for the determination of the expression of anti-protein p53 antibody (M7001 DAKO A/S, Denmark). Anatomo-clinical and demographic data were not significantly correlated with the presence of lymph node metastases or p53 expression in the tumor or in the adjacent normal mucosa. Tumor localization in the larynx was significantly correlated with p53 expression. Histological grading as grades I, II, III and IV was correlated with significant p53 expression (p=0.025). Conclusions: 1) in the studied material obtained from 63 cases of head and neck ECs, we detected a 48 percent rate of immunohistochemically detectable $\mathrm{p} 53$ overexpression; 2) we did not detect a relationship between demographic patient data and p53 expression in the tumor or in the normal adjacent mucosa; 3) p53 overexpression was significantly more frequent in ECs material from the larynx; and 4) The presence of 12 cases with p53 overexpression in the normal adjacent mucosa and with a p53-negative tumor is in agreement with the theory of field cancerization. Follow-up of this patient series for a longer period of time will permit a better analysis of these values.

UNITERMS: P53, squamous cell carcinoma, head and neck cancer, immunohistochemistry

\section{INTRODUCTION}

$\mathrm{E}$ pidermoid carcinomas (ECs) represent more than 90 percent of the neoplasias of the upper aerodigestive tract $^{6}$ and their incidence increases among subjects who smoke cigarettes and consume alcoholic beverages. ${ }^{12}$ ECs correspond to the sixth most frequent form of cancer in the world. ${ }^{9}$

\author{
Address for correspondence: \\ Angela Flavia Logullo \\ Rua Prof. Antonio Prudente, 211 \\ São Paulo/SP - Brasil - CEP 01509-010
}

Patients with head and neck ECs in the same stage may respond differently to different forms of treatment. ${ }^{2}$ Currently recognized prognostic factors are not sufficiently objective or standardized, and do not correspond to the biological behavior of the tumor at the cellular level.

The theory of field cancerization in head and neck neoplasias reflects the complex oncogenesis that occurs in this region. ${ }^{33}$ The frequent occurrence of multiple primary tumors in the upper aerodigestive tract may be explained by continuous exposure of the mucosa to various carcinogens. However, the sequential stages of this complex carcinogenesis have not been fully elucidated and the molecular mechanisms that control cell proliferation and the aberrant behavior of ECs in the upper aerodigestive tract are still unknown. 
Genes involved in carcinogenesis may be classified as proto-oncogenes and tumor-suppressor genes according to their action mechanism. ${ }^{23.35}$ Tumor-suppressor genes code for proteins with functions related to the control and suppression of cell growth and proliferation by transactivation or transrepression of specific genes. These genes actively affect the cell cycle, regulating it in a repressive manner."

The role of gene $\mathrm{p} 53$ has been the subject of several studies on solid human tumors. ${ }^{5.6 .15 .16 .18 .19 .25 .26,30}$ P53 mutations are the genetic alterations most frequently detected in head and neck ECs, ${ }^{28.34}$ specifically in the larynx, and seem to actively contribute to the carcinogenic process of the gene ${ }^{31}$ as a tumor suppressor and to its association with tobacco. ${ }^{4.10 .17}$

The accumulation of mutation of gene p 53 associated with head and neck ECs has been reported in the literature, although it has not been correlated with other prognostic factors. ${ }^{1.2 .7 .13} \mathrm{~A}$ better understanding of the role and mechanism of action of gene p53 in the various stages of carcinogenesis may be of help in terms of specific therapeutic approaches, and may identify new tumor markers for early diagnosis.

The objective of the present study was to investigate the expression of p53 protein in head and neck ECs by immunohistochemistry and to determine its relation to other prognostic factors.

Table 1

Correlation between p53 expression and demographic data

\begin{tabular}{|c|c|c|c|c|}
\hline \multirow[b]{2}{*}{ Variables } & \multirow[b]{2}{*}{ Categories } & \multicolumn{2}{|c|}{ p53 expression } & \multirow[b]{3}{*}{$\mathrm{D}=0.51$} \\
\hline & & $(+)$ & $(-)$ & \\
\hline \multirow[t]{2}{*}{ Sex } & male & 26 & 25 & \\
\hline & female & 4 & 7 & \\
\hline \multirow[t]{3}{*}{ Race } & White & 28 & 30 & $p=1.00$ \\
\hline & Asian & 1 & 0 & \\
\hline & Black & 1 & 1 & \\
\hline \multirow[t]{3}{*}{ Age } & $<45$ & 4 & 5 & $p=0.89$ \\
\hline & $46-60$ & 13 & 12 & \\
\hline & $>60$ & 13 & 15 & \\
\hline Family & present & 24 & 23 & $\mathrm{p}=0.45$ \\
\hline History & absent & 6 & 9 & \\
\hline Smoking & present & 26 & 25 & $p=0.424$ \\
\hline habit & absent & 2 & & \\
\hline \multirow[t]{2}{*}{ alcoholism } & present & 6 & 8 & $\mathrm{p}=0.485$ \\
\hline & absent & 22 & 19 & \\
\hline
\end{tabular}

\section{MATERIAL AND METHODS}

The study was conducted on 63 consecutive ECs cases not submitted to previous treatment registered at the Department of Head and Neck Surgery of the A.C. Camargo Hospital in 1994 and 1995. Tumor and normal adjacent mucosa specimens were collected during surgery and fixed in Carnoy solution. After fixation, the material was embedded in paraffin and $4 \mu \mathrm{m}$ thick sections were obtained and stained with HE. The material was then submitted to immunohistochemical reaction for the determination of the expression of anti-protein p53 antibody (anti-human p53 protein clone DO7, M7001 DAKO, A/S, Denmark).

\section{Immunohistochemistry}

The material was deparaffinized and immersed in a bath containing decreasing concentrations of xylol and ethyl alcohol. The antigen was recovered by treatment in a microwave oven under immersion in a nitric citrate solution, with 4 baths of 5 min each at maximum potency. Endogenous peroxidase $\left(\mathrm{H}_{2} \mathrm{O}_{2}\right)$ was blocked and the material was incubated $1: 100$ with primary antibody overnight at $4^{\circ} \mathrm{C}$, followed by incubation with $1: 200$ biotinylated secondary antibody for $30 \mathrm{~min}$ at $37^{\circ} \mathrm{C}$. After incubation with 1:800 StrepAB complex:HRP for $30 \mathrm{~min}$ at $37^{\circ} \mathrm{C}$ (DAKO StrepAB complex/GRP Duet, mouse/rabbit kit), the material was immersed in $60 \mathrm{mg}$ percent $\mathrm{DAB}(2,3$ diaminobenzidine tetrahydrochloride, Sigma Chemical Co., D5637) plus 1 percent dimethyl sulfoxide PA (Labsynth) for 5 $\min$ at $37^{\circ} \mathrm{C}$ and counterstained with hematoxylin.

When more than 20 percent of the tumor cell nuclei stained dark brown, the sample was considered positive. The same criterion was used for the evaluation of normal adjacent mucosa. Positive and negative controls were systematically performed for each reaction. 


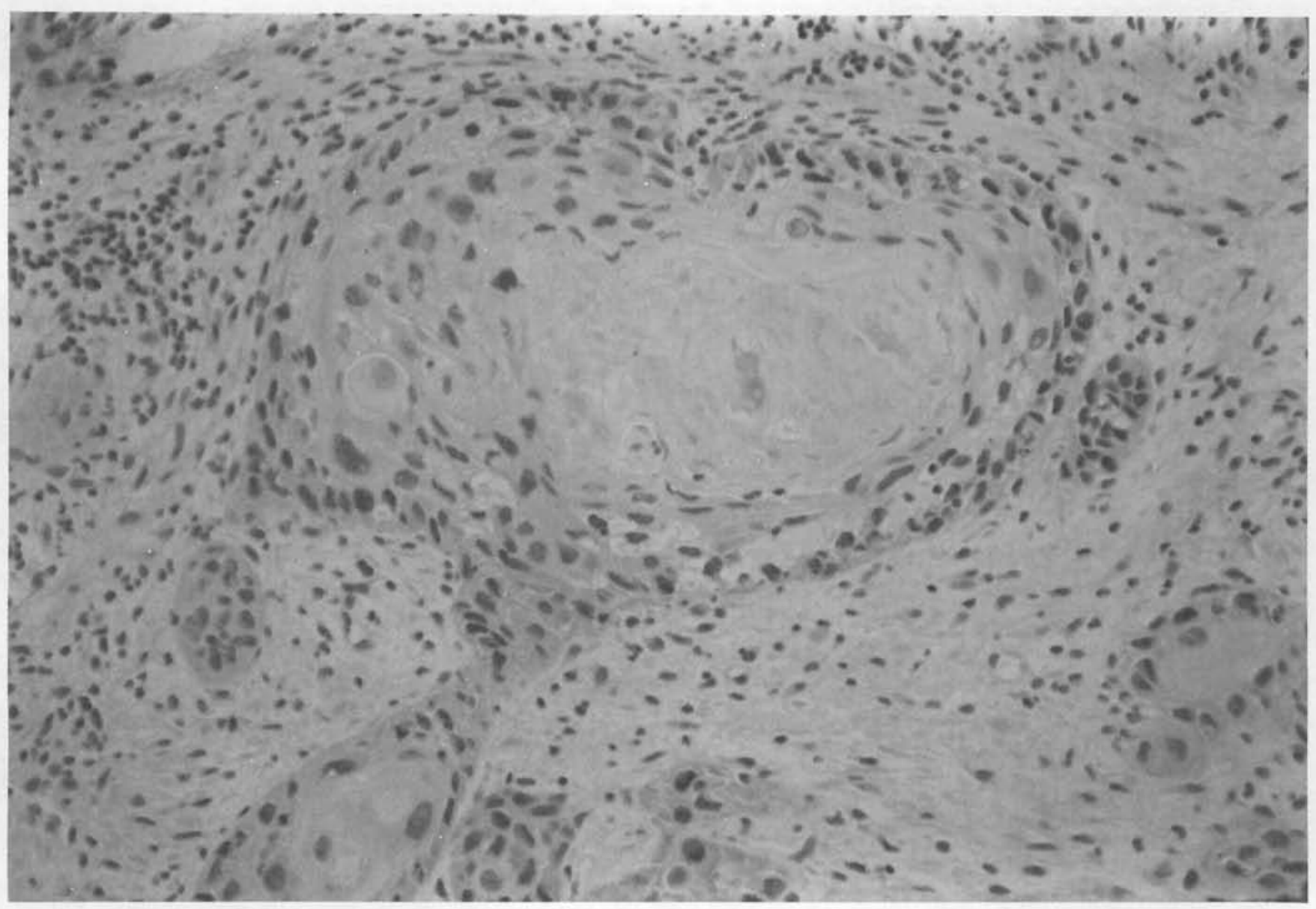

Figure 1 - p53 expression in grade II epidermoid carcinoma of the tongue.

\section{Statistical analysis}

Double-entry convergence tables were constructed for the analysis of correlations between the clinicalpathologic variables studied and the immunohistochemical expression of mutated $\mathrm{p} 53$ protein. Statistical significance was calculated by the chi-square test or by the exact Fisher test when applicable.

\section{RESULTS}

Expression of mutated p53 protein was considered to be positive in 30 of the 63 specimens of primary tumors (48 percent). The study did not show a significant correlation between protein $\mathrm{p} 53$ overexpression and patient demographic variables (family history of cancer, cigarette smoking or alcohol consumption) (Table 1). Cases for whom demographic data were not available were excluded from the table.

Figure 1 shows a grade II EC of the tongue with p53 overexpression.

To facilitate data analysis, the tumors were schematically assigned to the three following topographies: pharynx, including the cervical esophagus; oral cavity, including palate, mouth floor, tongue and gingiva; and larynx. Table 2 shows the correlation between p53 expression and anatomical location, histologic grade and lymph node status.

Epidermoid carcinoma of the larynx was significantly correlated with $\mathrm{p} 53$ expression which did not occur in other locations.

Histological grading was schematically divided into grades II. III and IV. Usually, grades III and IV have the best prognosis. Correlation with p53 expression was significant $(\mathrm{p}=0.025)$. No correlation was observed between 553 expression and presence of lymph node metastases. 


\section{Table 2}

Association between p53 expression and tumor topography, histological grade and lymph node involvement

\begin{tabular}{|c|c|c|c|c|}
\hline & & \multicolumn{2}{|c|}{ p53 expression } & $p=0.0225$ \\
\hline Tumor topography & & $(+)$ & $(-)$ & \\
\hline Oral cavity & & 15 & 18 & \\
\hline Pharynx & & 6 & 12 & \\
\hline Larynx & & 10 & 2 & \\
\hline Histological grade & & & & $p=0.025$ \\
\hline $1+I I$ & & 27 & 28 & \\
\hline III + IV & & 3 & 4 & \\
\hline Lymph node & negative & 17 & 14 & $p=0.20$ \\
\hline metastases & positive & 13 & 19 & \\
\hline
\end{tabular}

Mutations, deletions and amplification of the undeleted allele of gene p53 are commonly found in these lines..$^{37}$

Considering the multicentric etiology of tumors of the aerodigestive tract, several investigators have also examined the normal prelesional adjacent mucosa of some cases and have detected an irregular pattern of p53 expression, although they did not detect a correlation between $\mathrm{p} 53$

Data concerning p53 expression in the normal adjacent mucosa and in the tumor of the same patient are presented in Table 3. The results show that p53 expression at these two sites was not coincident in 29 cases. The tumor was $p 53+$ and the mucosa p53- in 17 cases, and 12 cases presented opposite results (a p53- tumor and a p53+ adjacent mucosa).

Figure 2 shows an area of the normal adjacent mucosa with moderate epithelial dysplasia and strongly p 53 positive. Figure 3 shows an area of normal adjacent mucosa that is negative for $\mathrm{p} 53$ overexpression.

Although the follow-up time of the present series is still short, three patients who presented recurrences had p53+ tumors, whereas only one case had a recurrence among patients without $\mathrm{p} 53$ expression. This small number of recurrences prevents statistical analysis.

\section{DISCUSSION}

The hypothesis of the participation of gene p53 in the process of carcinogenesis of head and neck tumors has been discussed in several studies. ${ }^{7-9.13 .14 .21 .24 .27 .29 .32 .34 .37}$ After the discovery of anti-protein p 53 antibodies, several retrospective studies have been published, with variable results, i.e., rates of p53 positivity of 30 to 67 percent. Thirty to 65 percent of the carcinomas have characteristic mutations in gene $\mathrm{p} 53$, with an allele usually having a point mutation and producing a mis-sense $\mathrm{p} 53$ protein that accumulates at high levels in cancer cells. The second allele was lost by conversion and/or genetic deletion..$^{22}$

Cell lines from ECs of the upper aerodigestive tract have revealed increased p53 expression in vitro. ${ }^{1.36}$ expression in the normal mucosa adjacent to the tumor and the appearance of a second neoplasia or recurrence. ${ }^{14,20.27 .29,32}$

Brachman et al. ${ }^{2}$ investigated 31 specimens of head and neck ECs and observed mutations of gene p53 in 53 percent of cases, demonstrated by polymorphism of single strand conformation. The same investigators later detected mutations in gene $\mathrm{p} 53$ by the polymerase chain reaction in 63 percent of the cell lines studied. Of the 31 cases of head and neck ECs studied by Chung et al., ${ }^{7} 21$ presented at least one mutation of gene p 53 , analyzed by the single chain polymorphism conformation method. Field et al.," in a study of 73 ECs cases, observed the presence of protein p53 overexpression in 67 percent of them by immunohistochemistry. In another immunohistochemical study, Frank et al. ${ }^{13}$ detected p53 overexpression in 37 percent of cases of ECs of the hypopharynx. Shin et al. ${ }^{32}$ obtained a 43 percent index in an immunohistochemical percent of the 63 head and neck ECs cases positive for p53 in our study is compatible with literature data.

In vitro studies carried out by Yin et al., ${ }^{37}$ Somers et al. ${ }^{34}$ and Weinberg et al. ${ }^{36}$ showed abnormalities of gene p53 in cell lines from head and neck carcinomas, such as overexpression of protein p53 demonstrated by immunohistochemistry and mutations and deletions of the gene detected by sequential analysis by the polymerase chain reaction.

Maestro et al ${ }^{24}$ investigated 58 cases of larynx tumors and found p53 overexpression in 60 percent using an immunohistochemical method and molecular analysis by the polymerase chain reaction and in situ hybridization. The authors concluded that this is the genetic alteration most frequently occurring in these tumors. Of 89 cases of ECs of the larynx studied by Nadal et al., ${ }^{27} 64$ percent presented immunohistochemically-detected p53 study of head and neck ECs. The presence of p53+ in 48 


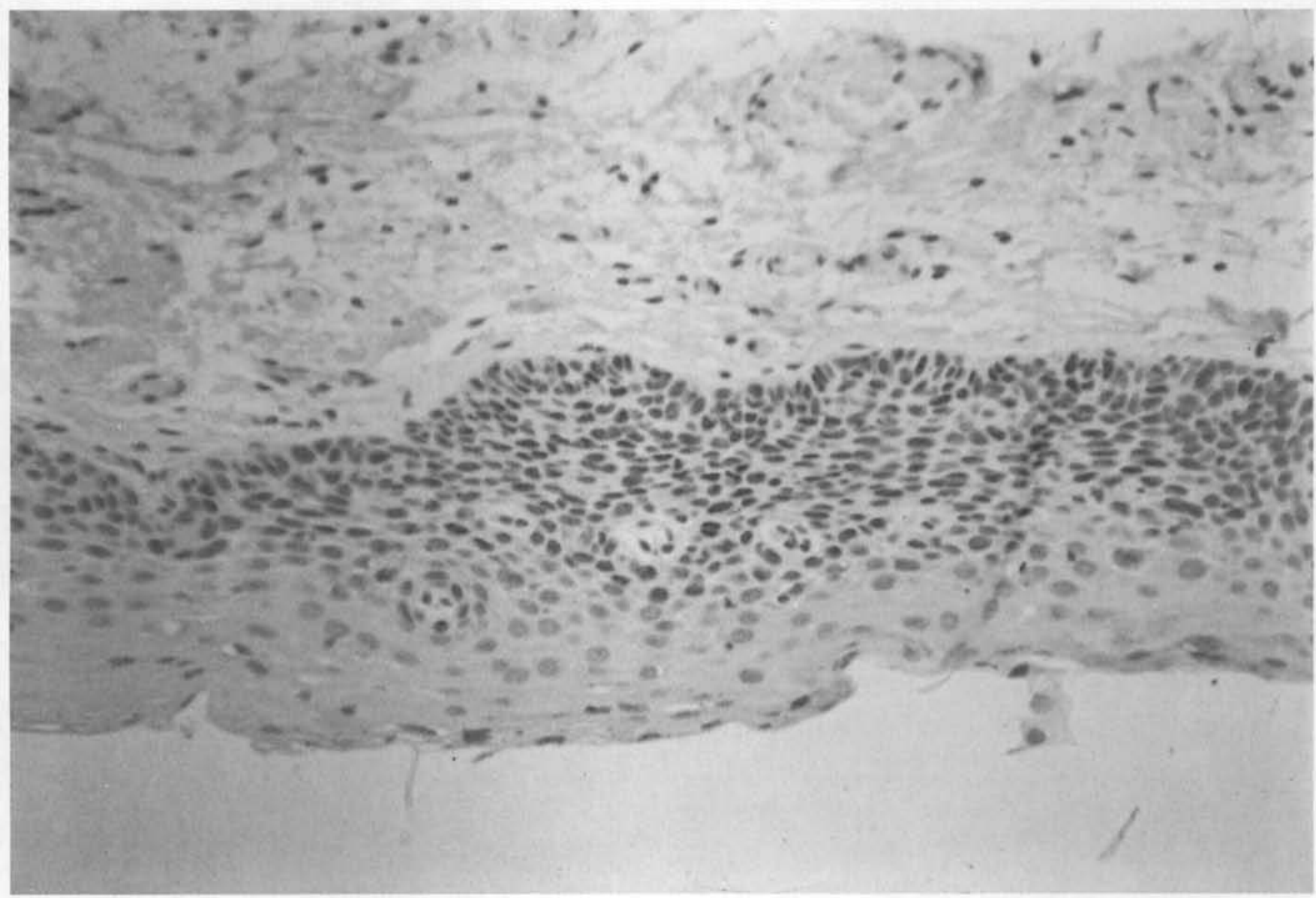

Figure 2 - Normal adjacent mucosa with moderate epithelial dysplasia and strongly p53 positive.

overexpression. The specific localization for these cases of cancer of the larynx was statistically significant in terms of p53 expression, a fact not previously reported.

The p53 overexpression observed in 10 of the 12 cases of cancer of the larynx studied here was more frequent than in the study discussed above. Nees et al. (1993) found p53 overexpression in only 44 percent of their cases of ECs of the larynx and in 80 percent of the cases of cancer of the oropharynx. We are currently expanding our study to determine $\mathrm{p} 53$ expression in the various topographies of the head and neck.

Prospective studies with appropriate material for analysis of p53 have only permitted a simple statistical correlation with some isolated factors such as smoking ${ }^{4.11}$ and human papillomavirus. ${ }^{3}$ The absence of a correlation between smoking and $\mathrm{p} 53$ gene expression in the present study disagrees with the data reported by others. ${ }^{2.4}$

With a longer follow-up time, few studies were consistent in showing the absence of a correlation between the prognostic factors normally used and p 53 expression in head and neck tumors. Frank et al. ${ }^{13}$ did not detect a correlation between p53 expression in ECs of the hypopharynx and other data such as incidence of secondary tumors, survival, ploidy or histological grade. Nadal et al. ${ }^{27}$ did not find a prognostic significance of p53 expression in neoplastic and dysplastic lesions of the larynx in a study of 89 cases, and concluded that the presence of mutations of gene p53 detected by the polymerase chain reaction is not correlated with radiosensitivity in these tumors.

Taking into account the theory of field cancerization, Nees et al. ${ }^{29}$ identified mutations of gene p53 in tumors and in the normal adjacent mucosa and suggested the participation of p53 in the carcinogenesis of multiple tumors. Shin et al. ${ }^{32}$ and Gusterson et al. ${ }^{14}$ studied premalignant lesions of the squamous epithelium, including dysplasia, hyperplasia, Bowen disease, and the normal adjacent mucosa and found 21 to 45 percent and 15 to 16.6 percent $\mathrm{p} 53$ positivity by immunochemistry in their respective series. The scarcity of data concerning 
survival prevented these authors from correlating their results with prognostic factors. However, there is no objective evidence of a correlation between $\mathrm{p} 53$ expression and prognostic factors for head and neck carcinomas. ${ }^{27}$

The absence of a correlation between the expression of p53 in the normal adjacent mucosa and in the tumor area of the same patients detected here agrees with literature data. Nees et al. ${ }^{29}$ found $\mathrm{p} 53$ overexpression in the normal adjacent mucosa and absence of $\mathrm{p} 53$ protein in patients with head and neck ECs This apparent discrepancy was observed in 12 of our cases. The presence of p53 expression in the adjacent mucosa may indicate the possible origin of multiple tumors or the local recurrence in this area through different carcinogenic processes, involving or not mutation of the p53 gene. The specific localization in cancer of the larynx was statistically significant in terms of p 53 expression, a fact that is not uncommon in literature reports. Our series must be expanded for a better analysis of the topographic distribution of tumors according to $\mathrm{p} 53$ expression.

\begin{tabular}{l}
$\begin{array}{c}\text { Table } 3 \\
\text { Expression of } \mathrm{p} 53 \text { in the primary tumor and in the } \\
\text { adjacent mucosa. }\end{array}$ \\
\hline \multicolumn{1}{c}{$p 53(+)$ expression p53(-) expression } \\
$\begin{array}{l}\text { p53(+) } \\
\text { expression }\end{array}$ \\
$\begin{array}{l}\text { p53(-) } \\
\text { expression }\end{array}$
\end{tabular}

\section{CONCLUSIONS}

1. In material obtained from 63 cases of head and neck ECs, we observed 48 percent immunohistochemicallydetectable p 53 overexpression, a rate compatible with literature data.

2. We did not observe a relation between patient demographic data and $\mathrm{p} 53$ expression in the tumor or in the normal adjacent mucosa.

3. p53 overexpression was significantly more frequent in material from ECs of the larynx.

4. The presence of 12 cases with p53 overexpression in the normal adjacent mucosa and a p53-negative tumor agrees with the theory of field cancerization. This finding may be a factor for the early detection of patients at high risk to develop other p53-positive tumors.

A longer follow-up of this series will permit a better analysis of these values in terms of recurrence and the possible appearance of other tumors, which is about 6 percent (unpublished data).

\section{ACKNOWLEDGMENTS}

We wish to thank Myiuki Fukuda da Silva and Carlos Ferreira Nascimento for technical assistance. A.F.I. is the recipient of a Doctoral fellowship from FAPESP.

\section{RESUMO}

A teoria de campo de cancerização em neoplasias de cabeça e pescoço (CP) reflete a complexa oncogênese que ocorre nesta regiāo. Os mecanismos a nivel molecular que controlam a proliferação celular em Carcinomas epidermóides (CEC) de vias aerodigestivas superiores ainda sāo pouco conhecidos. Mutaçōes no p53 sāo as alteraçōes genéticas mais encontradas em CEC de CP e parecem contribuir ativamente em seu processo carcinogênico como gene supressor de tumor e a sua associação com tabaco. O objetivo deste trabalho é analisar a expressão da proteina p53 em carcinoma epidermóide de cabeça e pescoço por meio de reaçāo imunohistoquimica e sua correlaçāo com outros fatores prognósticos, O estudo inclui 63 casos consecutivos de CEC, năo tratados previamente. Espécimes de tumor e de mucosa normal adjacente foram colhidos durante 0 ato cirúrgico e submetidos a reaçāo imunohistoquimica para avaliaçāo da expressâo do anticorpo anti-proteína p53 (M7001 DAKO A/S, Denmark Inc.) Nāo houve significância entre os dados anatomo-clinicos e demogràticos, presença de metástases linfonodais e a expressāo de p53 no tumor ou na mucosa adjacente normal. A localizaçāo do tumor na laringe apresentou correlaçāo estatistica significativa com a expressão da p53. A graduação histológica, separada em graus I e II, e III e IV apresentou correlaçāo com a expressāo de $p 53$ significante $(p=0,025)$. Conclusōes: 1-No material estudado proveniente de 63 casos de CEC de cabeça e pescoço encontramos $48 \%$ de superexpressăo de p53 imunohistoquimicamente detectável, indice compativel com os demais relatados na literatura; 2-Não encontramos relação entre os dados demográficos do paciente e a expressāo de p53 no tumor e na mucosa normal adjacente; 3- O achado de superexpressāo de p53 mais freqüente em material de CEC de laringe foi estatisticamente significativo. 4-A presença de 12 casos com superexpressāo de p53 na mucosa normal adjacente e com tumor p53 negativo está de acordo com a teoria de cancerizaçāo de campo. 0 seguimento desta série por maior tempo possibilitarà uma melhor análise destes valores. 


\section{REFERENCES}

1. Burns JE, Baird MC, Clark LJ, et al. Gene mutations and increased levels of p53 protein in human squamous-cell carcinomas and their cell lines. Br J Cancer 1993;67:127484.

2. Brachman DG, Beckett M, Graves D, et al. p53 mutation does not correlate with radiosensitivity in 24 head and neck cancer cell lines. Cancer Res 1993;53:3667-9.

3. Brachman DG, Graves D, Vokes E, et al. Occurrence of p53 gene deletions and human papilloma virus infection in human head and neck cancer. Cancer Res 1992;52:4832-6.

4. Brennan JA, Boyle JO, Koch WM, et al. Association between cigarette smoking and mutation of the $\mathrm{p} 53$ gene in squamouscell carcinoma of the head and neck. N Engl J Med 1995;332(11):712-17.

5. Chang F, Syrjanen A, Tervahauta A, et al. Tumorigenesis associated with the p53 tumor-suppressor gene. Br J Cancer 1993;68:653-61.

6. Chen PL, Chen Y, Bookstein R, Lee WH. Genetic mechanisms of tumor suppression by the human p53 gene. Science 1990;250:576-9.

7. Chung KY, Mukhopadhyay T, Kim J, et al. Discordant p53 mutations in primary head and neck cancers and corresponding second primary cancers of upper aerodigestive tract. Cancer Res 1993;53:1676-83.

8. Donehower LA, Bradley A. The tumor suppressor p53. Biochemica et Biophysica Acta 1993;155:181-205.

9. Field JK. Oncogenes and tumor-suppressor genes in squamous cell carcinoma of the head and neck. Oral oncol Eur J Cancer 1992;28B(1)67-76.

10. Field JK, Spandidos DA, Malliri A. Elevated p53 expression correlates with a history of heavy smoking in squamous-cell carcinoma of the head and neck. Br J Cancer 1991;64:573-77.

11. Finlay CA, Hinds PW, Levine AJ. The p53 proto-oncogene can act as a suppressor of transformation. Cell 1989;57:108393.

12. Franco LE, Kowalski LP, Kanda JL. Risk factors for second cancers of the upper respiratory and digestive systems: A case-control study. J Clin Epidemic 1991;4(7):615-25.

13. Frank, JL Bur ME, Garb JL, et al. p53 tumor suppressor oncogene expression in squamous-cell carcinoma of the hypopharinx. Cancer 1994;73(1):181-6.

14. Guterson BA, Anbazhagan R, Warren W, et al. Expression of p53 premalignant ad malignant squamous epithelium. Oncogene 1991;6:85-9.

15. Harris CC, Hollstein M. Clinical implications of the p53 tumor suppressor gene. N Engl J Med 1993; Oct 28:131825.

16. Hollstein M, Sidransky D, Vogelstein B, Harris CC. p53 mutations in human cancers. Science 1991;253:49-53.

17. Knudson A, Genetics of tumors of the head and neck. Arch Otolaryngol Head Neck Surg 1993;119:735-7.

18. Lamb P, Crawford ML. Characterization of the human p53 gene. Mol Cel Biol 1986;6:1379-85.

19. Lake D. Worrying about p53. Current Biol 1992;2(11):5813.
20. Lee NK, Ye YW, Chen J. p53, retinoblastoma, and human papilloma virus in squamous-cell carcinoma and adjacent normal mucos of the upper aerodigestive tract. Arch Otolaringol Head Neck Surg 1993;119:1125-31. 1992;

21. Leonard HL, Kearsley JH, Chenovix-Trench G, et al. Analysis of gene amplification in head and neck squamous-cell carcinomas. Int J Cancer 1991:48:511-15.

22. Levine AJ. The road to the discovery of the $\mathrm{p} 53$ protein. Int J Cancer 1994;56:775-6.

23. Levine AJ, Momand J, Finlay CA, The p53 tumor suppressor gene. Nature 1991;351:453-6.

24. Maestro R, Dolcetti R, Gasparotto D, et al. High frequency of p53 gene alterations associated with protein overexpression in human squamous-cell carcinoma o the larynx. Oncogene 1992, 7:1159-66.

25. Malkin D, Jolly KW, Barbier N, et al. Germline mutations of the p53 tumor-suppressor gene in children and young adults with second malignant neoplasms. N Engl J Med 1992;326:1309-25.

26. McBride OW, Merry D, Givol D. The gene for the $\mathrm{p} 53$ cellular tumor antigen is localized on chromosome 17 short arm (17p13). Proc Natl Acad Sci USA 1986;83:130-4.

27. Nadal A, Campo E, Pinto J, et al. p53 expression in normal, dysplastic, and neoplastic laryngeal epithelium. Absence of a correlation with prognostic factors. J Path 1995;175:181-8.

28. Nagai MA, Miracca EC, Yamamoto L, Kowalski LP, Brentani RR. TP53 mutations in upper aerodigestive squamous-cell carcinomas from a group of Brazilian patients. A J Surg 1996;170:92-4.

29. Nees M, Homann N, Discher H, et al. Expression of mutated p53 in tumor-distant epithelia of head and neck cancer patients: A possible molecular basis for the development of multiple tumors. Cancer Res 1993;53:4189-96.

30. Nigro JM, Baker SJ, Preisinger AC, et al. Mutations in the p53 gene occur in diverse human tumor types. Nature 1989;342:705-9.

31. Reiss M, Vellucci VF, Zhou ZL. Mutant p53 suppressor gene causes resistance to transforming growth factor in murine keratinocytes. Cancer Res 1993;53:899-04.

32. Shin DM, Kim J, Ro JY, et al. Activation of p53 gene expression in premalignant lesions during head and neck tumorigenesis. Cancer Res 1994;54:321-6.

33. Slaughter DP, Southwick HW, Smejkal, W. "Field Cancerization" in oral stratified squamous epithelium. Cancer 1953;6:963-8.

34. Somers KD, Merrick A, Lopez ME, et al. Frequent p53 mutations in head and neck cancer. Cancer Res 1992;52:5997-6000.

35. Weinberg RA. Oncogenes, antioncogenes and molecular basis of multistep carcinogenesis. Cancer Res 1989;49:37138.

36. Weinberg WC, Azzoli CG, Chapman K, et al. p53-mediated transcriptional activity increases in differentiating epidermal keratinocytes in association with decreased p53 protein. Oncogene 1995;10:2271-9.

37. Yin XY, Smith ML, Witesade TL, et al. Abnormalities in the p53 gene in tumors and cell lines of human squamouscell carcinomas of the head and neck. Int J Cancer 1993;54:322-7. 